\title{
JĀNIS PLIEKŠĀNS TIESĪBU IDEJAS MEKLĒJUMOS RAIN̦A FILOZOFIJĀ
}

\section{JĀNIS PLIEKŠĀANS IN SEARCH OF THE IDEA OF LAW IN RAINIS' PHILOSOPHY}

\author{
Jānis Lazdiņš, Dr. iur. \\ Latvijas Universitātes Juridiskās fakultātes \\ Tiesību teorijas un vēstures zinātṇu katedras profesors
}

\begin{abstract}
Summary
The article is dedicated to the legal philosophical views of poet Jānis Pliekšāns (Rainis) about freedom, the people and the state. For Rainis, these concepts constitute a united philosophical system, founded on the idea of a free, happy, socialist State of Latvia. Of course, all nations, not only Latvians, are entitled to a state of their own. However, the idea of a state is not eternal. With time, states will voluntarily unite in one socialist global state. Freedom, democracy and genuine respect for nations' rights differentiate Rainis from Pēteris Stučka and other communists. The author believes that, in the contemporary understanding, Rainis' socialist state would be a socially responsible state.
\end{abstract}

Atslēgvārdi: Rainis, brīvība, tauta, valsts.

Keywords: Rainis, freedom, nation, state.

\section{Ievads}

Dzejnieks Jānis Pliekšāns / Rainis (1865-1929) pēc izglīīibas bija jurists, kādu laiku strādāja arī par žurnālistu'1, bija citu tautu slavenu cilvēku darbu tulkotājs un atdzejotājs latviešu valodā, kā arī sabiedrībā pazīstams jaunstrāvnieks, marksistisku (sociālistisku) uzskatu paudējs un politiḳis ${ }^{2}$. Bez tiesību zinātṇu studijām dzejnieka tiesību filozofijas uzskatu veidošanā, domājams, īpaša vieta vēl ierādāma "Jaunās strāvas" laikam un marksistiskas (sociālistiskas) literatūras studijām.

Jaunstrāvnieku idejas neveidoja ne zinātnisku doktrīnu, ne vienotu uzskatu kopumu. "Jaunā strāva kā tāda nebija politiska, bet ieplūda tādā. Viṇa bija visaptveroša garīga kustība, kura savā sfērā ievilka ij sociolog̣iju, ij dabas zinātnes, ij literatūru un mākslas, ij sabiedrības dzīvi, ij sieviešu kustību, t. s. sieviešu emancipāciju, ij filozofiju, ij jaunu pasaules uzskatu meklēšanu." 3 Par šo laiku J. Pliekšāns rakstīja, ka "[1]īizi sabiedriskām, dzilāàm pārmaiṇām "jaunās strāvas” laiks lika

\footnotetext{
1 “Dienas lapas” žurnālists (1887-1895) un galvenais redaktors (1891-1895).

${ }^{2}$ Latvijas Sociāldemokrātiskās partijas biedrs. Tika ievēlēts par Satversmes sapulces un Saeimas deputātu.

${ }^{3}$ Rainis. Kopotie raksti. Rīga: Zinātne, 1983, 18. sēj., 626. lpp.
} 
pamatu visai mūsu modernai dzīvei līdz pat pēdējām dienām un pāri tām. Tā laika gars uztura sakarību mūsu dzìvē, sabiedriskos uzskatos un darbībā. Arī manis sabiedriska rakstura darbos tas pats gars ir visa saturētājs [..]"4.

Marksisms (sociālisms) 19. gs. beigās tika uzskatīts par proletariāta filozofiju. Krišjānis Valdemārs bija aprēḳinājis, ka aptuveni 3/4 no latviešu tautas pieder darbaḷaužu šḳirai. ${ }^{5}$ J. Pliekšāns jau jaunībā izlēma kalpot savai, t. i., latviešu, tautai. Tā kā lielākā tautas daḷa bija darbaḷaudis, Rainim principā bija jākḷūst par marksistu (sociālistu). Marksistiskās teorijas ietekme uz dzejnieku ir konstatējama virknē darbu. ${ }^{6}$ Piemēram, dzejolī "Maija dziesmā” tiek rakstīts:

\author{
Visapkārt ceḷas māktas tautas; \\ Kur kultūras, tur šķiru karš; \\ Pret mācējiem sauc maija maršs, \\ Tiek darba masas cīnā rautas \\ [..] \\ Šai cīnā strādnieki ir brāḷi, \\ Vai latviets, vāciet's, krievs vai žìds; \\ Tie jūtas viens, vai tuvi, tāḷi, - \\ Kur sarkans karogs, iet tie lìdz.?
}

Lai arī sociālistiskām idejām ir ietekme uz Raiṇa filozofiju, J. Pliekšānu diez vai var uzskatīt par pārliecinātu marksistu. Jāpiekrīt Zentai Mauriṇai, ka marksismu Rainis nekad nav uzṇēmis kā dogmu. Tas drīzāk bija laikmeta jaunvārds, kas simbolizēja cīnu pret visu sastingušo. ${ }^{8}$

Raina dzīve, dzeja, tulkojumi, pārdomas par kosmosu, ētiku, dvēseli, nāvi, nemirstību u. c. ar tiesību zinātni nesaistīti jautājumi ir ievērojami pētīti. Dīvaini, bet J. Pliekšāna kā jurista tiesību filozofijas uzskatu analīze faktiski ir palikusi ārpus pētnieku redzesloka. ${ }^{9}$ Vienā nelielā publikācijā nav iespējams apskatīt visus Raiṇa darbos ietvertos problēmu jautājumus. Par raksta mērḳi tiek izvirzìts trīs jēdzienu - brīvība, tauta un valsts - kopsakarību analīze Raiņa tiesību filozofijā. Autora ieskatā, šo jēdzienu nozīmes izpratne Raiṇa atstātā intelektuālajā mantojumā nav zaudējusi aktualitāti arī mūsdienās.

${ }^{4}$ Rainis. Kopotie raksti. Rīga: Zinātne, 1983, 18. sēj., 626. lpp.

5 Birkerts A. Rainis kā domātājs. Rīgā: A. Raṇķa grāmatu tirgotavas apgādībā, 1925, 27.-28. lpp.

${ }^{6}$ Sk. salīdzinoši, piemēram, Markss K., Engelss Fr. Komunistiskās partijas manifests. [B. v.]: Zvaigzne ABC, 2008: "Sākumā cīnās atseviški strādnieki, tad vienas fabrikas strādnieki, vēlāk vienas darba nozares strādnieki vienā apvidū pret buržuju, kas tos tieši ekspluatē" (13. lpp.); "Katras zemes proletariātam, protams, vispirms jātiek galā ar savu pašu buržuāziju” (16. lpp.); "modernais rūpniecības darbs, modernais kapitāla jūgs - Anglijā tāds pats kā Francijā, Amerikā tāds pats kā Vācijā - atṇēmis tam jebkuru nacionālu raksturu" (15. lpp.) utt.

7 Rainis. Kopotie raksti. Rīga: Zinātne, 1978, 5. sēj., 235.-238. lpp.

${ }^{8}$ Mauriņa Z. Vadmotīvi Raiņa mākslā. Grām.: Latviešu literatūras vēsture. Virsredaktors prof. Dr. phil. h. c. Ludis Bērziņš. Redaktori: Kārlis Egle, priv.-doc. Kārlis Kārkliņšs, Zenta Mauriṇa. Rīgā: izdevusi "Literatūra", 1936, IV. sēj., 170. lpp.

9 Par izṇēmumu jāuzskata Ditas Amoliņas raksts “Rainis. Latvijas valsts idejas "gals un sākums'”' (sk.: Jurista Vārds, 2015, Nr. 45 (897), un šĩ raksta autora raksts "Jānis Pliekšāns' (Rainis') "Formula of Happiness"” (sk.: Journal of the University of Latvija. Law, 2020, No. 13). Par Raini kā internacionālu patriotu padomju varas gados rakstīis Zigurds Mikainis (sk. turpmākās atsauces). 


\section{Brīvība}

Cilvēka (indivīda) un tautas brīvības ideja ir viena no centrālām tēmām Raiņa filozofijā. Brīvība ir vērtība gan indivīdam, gan tautai kā indivìdu kopumam. Tautas brīviba ir neatkarīga valsts.

Krievijas impērija nevienai tautai brīvību nedāvāja. Jebkurai tautai tā bija jāizcina. Tiesību un cinnas jautājumā Rainis ir tuvs prof. Rūdolfa fon Jēringa slavenās publikācijas "Cinna par tiesībām" izvirzìtai tēzei par to, ka jebkura tiesība šajā pasaulē ir izcīnīta ${ }^{10}$, un proti:

\section{Cik varas būs, \\ Tik tiesibas; - \\ Tās ḷaudis gūs, \\ Tik jācīnās. ${ }^{11}$}

Rainis aicināja tautu, un it īpaši tās jaunatnes dal̦u, saprast, ka brīvības izcīnīšana prasa milzìgu garīgo un fizisko spēku piepūli. Ar aprēḳināmu risku būs par maz ${ }^{12}$, jo šajā cinṇā ir jāspēj uzvarēt:

$$
\begin{aligned}
& \text { Lai ir grūt', } \\
& \text { Vajag spēt: } \\
& \text { Stipram būt } \\
& \text { Uzvarēt. }{ }^{13}
\end{aligned}
$$

Ar atsevišķu cilvēku pūlēm sasniegt lielus mērḳus ir grūti. "Visai tautai, ne tikai atsevišķiem cilvēkiem, jātiecas pēc atbrīvošanas." ${ }^{14}$ Kolektīvās gribas sasniegšanas metode aprakstìta dzejolī "Jaunais laiks":

Ik vienam ir rokas jāpieliek, Lai lielais darbs uz priekšu tiek. ${ }^{15}$

Šì doma tiek turpināta lugā "Daugava", paskaidrojot "lielā darba" praktisko īstenošanas mehānismu:

\section{Kurš nenes ieročus, Dod roku darbu, Dod savu mantu, Dod savu prātu! ${ }^{16}$}

Alegoriski "[b]rīvību un brīvības cīṇu [kā raksta Antons Birkerts] Rainis mēdz pielīdzināt saulei un viņas darbỉbai. Kā saule izvilina no tumšā zemes klēpja dzīvību - zāli, puķes - tā brīvība rada dzīiību un prieku, pārvērtības sabiedrības nomāktajā daḷā"17. Saule simbolizē arī cīnu pret nakti un tumsu. Saules cinna pret tumsu nozìmē to pašu, ko cilvēku cinna pret apspiestību. ${ }^{18}$ Apspiestība ir

\footnotetext{
10 “Cīṇā Tev būs iegūt Tavas tiesības." “Tai brīdī, kad tiesības pamet savu cīṇas gatavību, tās pamet pašas sevi." Sk.: Jērings R. fon. Cīṇa dēẹ tiesībām. Pēterburga: A. Gulbja apgādībā, [b.g.], titullapa, 65. lpp.

11 Rainis J. Kopotie raksti. Otrs sējums. Dzeja. Rīgā: Latvijas Valsts izdevniecība, 1948, 422. lpp.

12 Ziedonis A. Jāṇa Raiṇa reliǵiskā filozofija. Rīga: Zinātne, 1994, 116. lpp.

13 Cit. no: Birkerts A. Rainis kā domātājs, 61. lpp.

14 Ziedonis A. Jāṇa Raiṇa reliǵiskā filozofija, 116. lpp.

15 Rainis. Kopoti raksti. Rīga: Zinātne, 1977, 1. sēj., 240. lpp.

16 Rainis. Kopotie raksti. Rīga: Zinātne, 1981, 12. sēj., 235. lpp.

17 Birkerts A. Rainis kā domātājs, 79. lpp.

18 Ziedonis A. Jāṇa Raiṇa reliǵiskā filozofija, 206. lpp.
} 
pretstats brīvībai, respektīvi: apspiestība ir l̦aunums, kas neḷauj attīstīties ne indivīdam, ne tautai. Tāpēc drāmā "Uguns un nakts" Lielvārds Lāčplēsim nosaka šādu virsuzdevumu:

Tev karot būs pret visu l̦aunumu,

Vai naidnieks rietumos vai austrumos.

Mums dzimtu kungu nav, mès paši vēlam

Sev mierā soğus, karā vadon,us,

Bet pārāks nav neviens par otru;

Tas mùsu spēks. - Ej, sargi Latviju,

Un pacel vinu citu zemju starpā. ${ }^{19}$

Tātad J. Pliekšāns brīvību Raiṇa filozofijā rod kā indivīda un tautas kopīgi izcīnāmu vērtību. Latviešu tautas brīvība balstās visu vienlīdzībā un tautas vadoṇu demokrātiskā vēlēšanu sistēmā.

\section{Tauta}

Jau skolas gados J. Pliekšāns sāka interesēties par tautu pašnoteikšanās tiesībām. Šì interese nezuda arī studiju gados. Latviešu valsts gribas formēšanās gados "Dienas Lapā" (1887) tika publicēts raksts "Īrija un Glastsons". Rakstā tika izvirzìta tēze, ka "katrai tautai, kas spēj uzturēt sevi pašuzturēšanās cīṇā, ir tiesības uz pašvaldību”"20. Pēc dzimtbūšanas atcelšanas Krievijas impērijas Baltijas guberñās (1816-1819) latvieši bija pierādījuši spējas uz pastāvīgu dzīvi. 19. gs. beigās bija pienācis laiks prasīt visu latviešu apdzīvoto zemju apvienošanu vienā Latvijas nacionālā pašvaldībā.

Politiskā situācija strauji mainījās 20. gs. sākumā, īpaši pēc tā dēvētās 1905. gada revolūcijas. Lìdz Latvijas valsts izsludināšanai un tās pirmajos pastāvēšanas gados par latviešu tautas nacionālās attīstības apdraudējumu kḷuva lielinieku (boḷ̌ševiku) sludinātais kosmopolītisms. Tā, piemēram, sarakstē ar Paulu Daugi Dauges personā Rainis pārmet visiem latviešu lieliniekiem ${ }^{21}$ nacionālo kultūras vērtību ignorēšanu:

Mès tik maz esam pārliecināti par savu pastāvēšanu, nesen bijām kārklu vāci un spaḷu krievi, nu esam kosmopolìti [..]. Tikai es atzīstu Latvijai un latvietìbai ne vien eksistences tiesību kā Tu, bet taisni gribu, lai mēs dzìvotu kā tauta, kā latvji. ${ }^{22}$ Kad partija atmet tautisku kultūru, tad top par pārkrievinātāju, jo bez tautiskas valodas un kultūras nau nevienas nācijas un tautas. Neesiet jel akli, redzat jel logisko kḷüdu. ${ }^{23}$

Tautu jautājumā Rainis strikti nostājas pret galēji kreisajiem, norādot, ka neviena tauta "[..] negrib mirt kā tauta un atdzimt kā proletariāts"24. Rakstot par kosmopolītisma jautājumu, Rainis būtībā pieliek punktu diskusijai ar P. Daugi:

19 Rainis. Kopotie raksti. Rīga: Zinātne, 1981, 9. sēj., 188. lpp.

${ }^{20}$ Rainis. Kopotie raksti, 5. sēj., 29. lpp.

${ }^{21}$ Starp visiem citiem latviešu lieliniekiem noteikti jāmin draugs un savulaik domubiedrs Pēteris Stučka.

22 Cit. no: Biezais H. Smaidošie dievi un cilvēka asara. Plön: Senatne, 1991, 19. lpp.

23 Turpat.

24 Cit. no: Mikainis Z. Humānisma un proletāriskā internacionālisma ideju vienotība Raiņa darbos. Rīga: Latvijas PSR Zinību biedrība, 1983, 22. lpp. 
Par tautas eksistenci nevar tikt päri tautas noliedzot. Cilvēces nacionālam attīstības posmam nevar pārlēkt pāri, ielecot beztautu kosmopolìtismā. Tā ir tikpat neloğiska t. i. nedialektiska un neevolucioniska domāšana, pretī attīstības likumiem, kāda parādījās savā laikā pie krievu narodņikiem, kas gribēja neiet cauri kapitālisma posmam un taisni ielēkt sociālisma iekārtā. ${ }^{25}$

Rainim kā dialektiķiem ir skaidrs, ka lìdz tautu kosmopolīismam katrai tautai jānonāk organiskas attīstības ceḷā brīvprātīgi, bez spējiem "rāvieniem" un "lēcieniem". Lielas tautas gan izturas egoistiski pret mazām tautām. Tomēr agrāk vai vēlāk visas tautas piemeklēs viens un tas pats liktenis - "mirt" kā tautai un "augšāmcelties" kā vienotai cilvēcei:

\section{Jā, mūsu tauta mirs, - mès zinām gan [..] \\ Bet citu lielu vārdu sakat man: \\ Vai nemirsat tāpat jūs, lielās tautas? \\ I jums, es dzirdu, kapa zvani zvan [..] \\ Tiks beigās visas tautas nāvē rautas, \\ Lai celtos atkal, cilvēcībà skautas. ${ }^{26}$}

Tātad J. Pliekšāns tautu Raiṇa filozofijā redz kā nacionāla gara (vērtību) attīstības garantu. Tautas ideja gan nav mūžīga. Izdzīvojot nacionālo attīstības posmu, tautas pakāpeniski saplūdīs, lai sasniegtu mērḳi - jaunu cilvēcības attīstības pakāpi.

\section{Valsts}

Valsts teorijā J. Pliekšāns ievērojami ietekmējās no antīko domātāju darbiem. İpaši mị̄š bija Aristotelis. No renesanses un apgaismíbas laika autoriem Makjavelli, Bodēns, Ruso u. c. ${ }^{27}$ Jauno laiku autoru vidū bez marksistiem var saskatìt arī prof. Georga Jellineka valsts teorijas (tauta ${ }^{28}$, teritorija un vara) ${ }^{29}$ ietekmi uz J. Pliekšānu. Raiņa triāde gan ir tauta, zeme un valsts. Tas, ka Raiņa triādē nav "varas", bet ir "valsts", autora ieskatā, nedrīkst samulsināt. Latvijas valsts pastāv tikai dzejnieka pēdējos 10 dzīves gadus. Pirms tam valsts ir mērḳis, kas vēl jāizcīna, un par "varu" vēl ir pāragri runāt. Arī dzejas rindās starp zemi un valsti bieži izzūd robeža:

Zeme, zeme, kas tā zeme,

Ko tā mūsu dziesma prasa?

- Zeme tā ir - valsts.

Paša zemi, paša valsti,

Dzìvi paša darinātu,

Paša valstī kungs. ${ }^{30}$

${ }^{25}$ Rainis J. Dzīve un darbi. Rīga: A. Gulbja apg., 1925, 9. sēj., 378.-379. lpp.

${ }^{26}$ Rainis. Kopotie raksti. Rīga: Zinātne, 1977, 2. sēj., 164. lpp.

${ }^{27}$ Mikainis Z. Rainis internacionālists un patriots. Rīga: Liesma, 1978, 201. lpp.

${ }^{28}$ Latvijas literatūrā jēdziena "tauta" vietā bieži raksta "iedzīvotāji”.

29 Deutsche und Europische Juristen aus neun Jahrhunderten. Eine biographische Einführung in die Geschichte der Rechtswissenschaft. 5., neu bearbeitete und erweiterte Auflage. Heidelberg: C. F. Müller Verlag, 2008, S. 25-30.

${ }^{30}$ Rainis. Kopotie raksti, 12. sēj., 223. lpp. 
Pirmā pasaules kara laikā (1915-1916) frontes līnija sadala latviešu zemes tā dēvētā "okupētā" Vācijas teritorijā un "neokupētā" Krievijas impērijas daḷā. Draud 17. gs. poḷu-zviedru kara sekas, kad tika sadalìta latviešu zeme un tauta. Vēsturiskie notikumi var kḷūt par nepārvaramu šḳērsli vienotas latviešu valsts izsludināšanai. Castagnol'ā (Šveicē) (turpmāk - Kastaņolā) Rainis uzsāk rakstīt zināmu lūgsnu par latviešiem un viṇu zemi. 1916. gada 5. jūlijā top dzejolis "Mēs un mūsu vienotā zeme", kurā pausta doma par latviešu zemju nedalāmību. ${ }^{31}$ Dzejas rindas 1919. gada septembrī tiek apkopotas un publicētas lugā "Daugava" īsi pirms Bermonta-Avalova (krievu-vāciešu "brīvprātīgo") armijas uzbrukuma Rịgai. "Daudziem [latviešu] kara vīriem, gan tieši frontē, gan atpūtas brīžos tuvākā aizmugurēe, varēja redzēt rokā "Daugavu", kur tie smēlās sajūsmu: sakarā ar to daži kara vadoṇi bij izteikušies, ka Raiṇa "Daugava” atsvērusi veselu pulku [..." 32 :

\section{Dauvgav' abas malas \\ Mūžam nesadalās: \\ I Kurzeme, i Vidzeme, I Latgale mūsu.<smiles>[AlH2]</smiles> \\ Laime, par mums lemi! \\ Dod mums mūsu zemi! \\ Viena mèle, viena dvēsle \\ Viena zeme mūsu. ${ }^{33}$}

1917. gadā sabrūk Krievijas impērija. Sapnis par brīvu Latviju kḷūst reāls. Tiek uzsākta lugas "Spēlēju, dancoju” publicēšana. Lugas galvenā varonē Leldē Rainis simbolizē vēl izcīnāmo Latviju, aicinot:

$$
\begin{gathered}
\text { - Kalsim sirdis, kalsim bruņas! - } \\
\text { - Varoños brīvi tapsim - } \\
\text { - Saule celsim jauno Latvi! } !^{34}
\end{gathered}
$$

1918. gada 18. novembrī tiek izsludināta Latvijas Republika. Par godu šim notikumam Rainis patriotisku jūtu uzplūdos raksta:

Vienā tumšā vakarā

Sarkan-balta debess mirdz, -

Sarkan-baltās debesīs

Atviz trijas zelta zvaigznes.

Viena zvaigzne Kurzemīte,

Otra zvaigzne Vidzemite,

Trešà zvaigzne zvaigznājā

Tā bij mīlā Latgalīte. ${ }^{35}$

\footnotetext{
${ }^{31}$ Rainis. Kopotie raksti, 12. sēj., 477. lpp.

${ }^{32}$ Rainis. Kopotie raksti, 18. sēj., 595. lpp.

33 Rainis. Kopotie raksti, 12. sēj., 222. lpp.

${ }^{34}$ Rainis. Kopotie raksti. Rīga: Zinātne, 1981, 11. sēj., 478. lpp.

35 Rainis. Kopotie raksti, 12. sēj., 234. lpp.
} 
Latvija ir izsludināta kā republika uz demokrātiskiem pamatiem. ${ }^{36}$ Tobrīd tas bija vēl tikai ietvars, kas bija jāpiepilda ar saturu.

\section{Ideālā valsts}

Rainim līdzīgi Platonam ir sava “ideālā valsts". ${ }^{37}$ Pēc 1905. gada revolūcijas prasība par brīvu Latviju brīvā Krievijas Federatīvā Republikā ${ }^{38}$ pakāpeniski zaudē savu nozīmi. Kastaņolas laikā J. Pliekšāns no šìs domas atsakās galīgi. Tiek rakstīts un runāts par brīvu sociālistisku Latviju un jaunu, brīvu sociālistisku pasauli. ${ }^{39}$

Pētot Raiṇa intelektuālo mantojumu, Jānis Kalniņš ir secinājis, ka "Rainis ne mirkli neraudzījās uz Padomju Savienību kā uz valsti, kur tiek realizēts viṇa sapnis par sociālismu" ${ }^{40}$. Tas ir pašsaprotami. Ja Krievijas impērija savulaik tika uzskatīta par "tautu cietumu", tad ši "cietuma vārtus boḷ̌seviki aizvēra pavisam"41. Šajā ziṇā jāpiekrīt Haraldam Biezajam, ka Rainis "meklēja ceḷu uz pozitīvo sociālismu. Tas nebija saskaṇojams ar [..] proletariāta diktatūru"42. Citādi ne pret PSRS, ne kādu citu valsti dzejnieks neizturējās ar naidu. Pastāvēja tikai viens nosacijums:

\section{Mēs tikai negribam, ka mūs spaida. \\ Mēs negribam kalpot ne austrumam, Mès negribam vergot ne rietumam. ${ }^{43}$}

Līdzīgi Džonam Lokam ${ }^{44}$, arī Rainim brīvība (brīva valsts) ir cieši saistīta ar laimi. ${ }^{45}$ Nāves salā, tiekoties ar Spīdolu, Lāčplēsis saka:

\section{Kad laimìga, brìva būs Latvija, Tad mana gaita būs izbeigta. ${ }^{46}$}

Aristotelis bija pārliecināts, ka nav viegli darīt labus darbus, dzīvojot nabadzībā. Nepieciešama arī labklājība. Trūkums aizēno laimi. ${ }^{47}$ Trūkumā arī Rainim nav iedomājama laime. Pretēji antīkajā pasaulē pastāvējušai ievērojamas sabiedrības daḷas verdzībai J. Pliekšāns kā marksists (sociālists) prasa:

\footnotetext{
36 Sk.: Latvijas pilsoņiem! Pagaidu Valdības Vēstnesis, 1918. g. 14. (1.) decembrī, Nr. 1; Latvijas Tautas Padomes politiskā platforma, II. panta 1) punkts. LNA, LVVA, 1307. f., 1. apr., 327. 1., 27.-29. lp.

37 Sk. Platons. Valsts. Rīgā: Zvaigzne, [b.g.].

38 vai: sociālistiskā Krievijas federācijā. Sk., piemēram: Biezais H. Smejošie dievi un cilvēka asara, 21. lpp.

39 Kalniņš J. Rainis - derīgais un nederīgais. Eseja. (Kādas inkvizīcijas sakarā.) Pārdomas un atmiņas. [B. v.]: Signe, [b.g.], 63. lpp. Sk. arī: Biezais H. J. Smaidošie dievi un cilvēka asara, 22.-23. lpp.

40 Turpat, 31. lpp.

${ }^{41}$ Biezais H. J. Smaidošie dievi un cilvēka asara, 20. lpp.

42 Turpat, 30. lpp.

${ }^{43}$ Rainis. Kopotie raksti, 12. sēj., 223. lpp.

${ }^{44}$ Sk.: Locke J. An Essay Concerning Human Understanding. Hertfordshire: Wordsworth classics of world literature, 2014, pp. 224-270.

45 Sk.: Lazdinš̌ J. Jānis Pliekšāns' (Rainis') “Formula of Happiness”, pp. 153-163.

${ }^{46}$ Rainis. Kopotie raksti, 9. sēj., 262. lpp.

47 Aristotelis. Nikomaha ètika. Rīga: Zvaigzne, 1985, 39. lpp.
} 
Ļauj Latvijā gaišiem tapt visiem prätiem, L̦auj visām sirdìm laimību just,

Lauj visām vaimanām klust.

Lai visi vienādā piln̄̄bà staigā:

Lai visiem darbs, lai visiem dusa,

Lai katram vala pēc saules sniegties. -

Lai dīgli dvēselè un galvā nau jāapspiež,

Lai visi var zelt, tad tauta augs,

Kā puķu dārzs, tāḷ smaržojot, plauks. ${ }^{48}$

Tātad J. Pliekšāna ideālā Latvija Raiṇa filozofijā ir brīva un laimīga sociālistiska valsts. Šeit cilvēkiem ir darbs, miers (visas vaimanas ir klusušas) un vienlīdzīga labklājỉba (visi vienādā pilnībā staigā). Šādā valstī katrs var "pēc saules sniegties" (t. i., pēc augstākas pakāpes brīvības un arvien lielākas laimes). Autora ieskatā, mūsdienu izpratnē tā būtu sociāli atbilstīga valsts.

\section{Kopsavilkums}

1. Rainim jēdzieni - brīvība, tauta un valsts - veido vienotu filozofijas sistēmu, kuras pamatā likta doma par brīvu, laimīgu sociālistisku Latvijas valsti, kas nodrošina uz vienlīdzības un demokrātijas pamatiem darbu, mieru, vienlīdzīgu labklajjību un personas attīstības iespējas.

2. Sociālistiska Latvija mūsdienu izpratnē būtu sociāli atbildīga valsts. PSRS nebija Raiņa ideālās valsts prototips.

3. Ar laiku visas tautas un valstis "mirs" un "augšāmcel̦oties" saplūdīs sociālistiskā pasaulē. Lai arī tas notiks cilvēcības vārdā, šo procesu nedrīkst steidzināt. Katrai tautai ir tiesības izdzīvot savu nacionāli valstisko attīstības posmu.

Raksts izstrādāts valsts pētījums programmas "Latvijas mantojums un nākotnes izaicinājumi valsts ilgtspējai" projektā "Indivīda, sabiedrības un valsts mijiedarbība kopējā Latvijas vēstures procesā: vērtību konflikti un kopīgu vērtību veidošanās vēsturisku lūzumu posmos" (projekta Nr. VPP-IZM-2018/1-0018).

${ }^{48}$ Rainis. Kopotie raksti, 9. sēj., 220. lpp. 